\title{
Case Studies on Coastal Wetlands and Water Resources in Nigeria
}

\author{
H.O Nwankwoala ${ }^{1}$
}

\begin{abstract}
Wetlands play a very important role in the sustenance of both the surface and groundwater resources of the country. It is sad to observe that the country is fast losing her wetlands, as the rich wetlands are being seriously threatened by a number of anthropogenic and biophysical factors. Some of the notable human actions include population pressure, rapid urbanization, mining, oil and industrial waste pollution, overgrazing, logging, dam construction, transportation routes and other physical infrastructure. Others factors are uncontrolled tilling for crop production and unprecedented/unregulated land reclamation. Subsidence, saltwater intrusion, sand storm, desertification and droughts, invasion by alien floral and faunal species as well as marine and coastal erosion are natural threats to wetlands in Nigeria. Wetlands destruction affects negatively water supply and water resources management. This study examines in great detail the fate of wetlands in the face of climate change and recommends that efforts should be made to accurately document the country's wetland. The paper therefore suggested sustainable options for wetlands and water resources management in Nigeria. This, the paper opined, can be done through the strengthening of wetlands preservation and conservation regulation, mitigating the effects of climate change as well as the development of deliberate restoration programmes and policies aimed at sustaining degraded wetlands in Nigeria.
\end{abstract}

Key words: Water, wetlands Resources, climate change, coastal ecosystem, biodiversity, Nigeria.

\section{Introduction}

Wetlands are important elements of Nigeria's watershed systems (Uluocha \& Okeke, (2004); Asibor, (2009); Chidi \& Ominigbo, (2010). A great deal of the hydrological and water resources problems currently experienced in Nigeria are the resultant effects of wetland degradation in the country. The challenges posed

${ }^{1}$ Department of Geology, University of Port Harcourt, Nigeria E-mail: nwankwoala ho@yahoo.com, 
by the degradation can better be understood and better appreciated when viewed against the backdrop of the benefits derivable from the wetlands.

The current use and management of water and wetland resources is dominated by the construction of large dams to store much of the available water for hydropower, irrigation and urban water supply. This practice, which serves to exacerbate the climate variability and change impacts, has often left too little for maintaining the traditional wetland function downstream and caused significant stream flow regime change in most of the major wetlands in Nigeria.

It has been estimated that a rise in sea level by up to $59 \mathrm{~cm}$ will see several of Nigerian coastal states being submerged in waters and floods (Onyeka \& Adaobi, 2008). Such events will no doubt, disrupt the life and occupations of the inhabitants such as fishing, farming etc as well as wreck great havoc on the ecological balance (Chidi \& Ominigbo, 2010). The projected impact of climate change on water and wetland resources would be all pervasive. Physical changes in the hydrological cycle (driven by both climate change and human modification of the systems) in the case of reduced rainfall and/or increased evaporation would disconnect rivers from their floodplains and wetlands and slow water velocity in riverine systems, converting them into a chain of connected reservoirs or pools. These in turn impact the migratory patterns of fish species and the composition of riparian habitat, opens the way for exotic species, and contributes to an overall loss of freshwater biodiversity and inland fishery resources and agricultural productivity of traditional systems and ecosystems long adapted to the flood regime.

UNEP (2007) alerts that globally, wetlands have been reduced by $50 \%$. It is estimated that one third of all endangered species are dependent on wetlands (Asibor, 2009). Though, Nigeria contributes less to the global green house effect, the country remains the most vulnerable to the adverse effects of global warming and climate change (Bonfis, 2001). Climate change is expected to impact adversely on wetland functions through change in hydrology, biogeochemistry and biomass accumulation. Particularly, climate change is expected to cause melting of sea ice, rise in sea levels, change in oceanic circulation patterns, species extinction, salt water intrusion, loss of habitat, higher storm frequency and intensity, flooding in the coastal regions, amongst others (Dietrich, 2005; Kusler, 2003). The combined adverse effects of mineral exploitation and climate change are enormous, hence the need for serious studies to protect wetlands. 
Strategy for preparedness and adaptation to impacts of climate change on water resources and wetlands is very desirable. This paper therefore advocates that there is the challenging need to protect the wetlands to ensure that they will continue to provide their essential goods and services as well as ensure the sustenance of the surface and groundwater resources of Nigeria.

\section{Water and Wetlands Resources of Nigeria}

Nigeria is naturally endowed with abundant surface and groundwater resources, but the water supply situation in the country for various uses remains far below expectation (Nwankwoala, 2011; Offodile, 2006; Tijani, 2006; Uluocha \& Okeke, 2004). Aggravating the problem of water management in the country is the fact that wetlands, which naturally recharge and protect both the surface and groundwater resources, are being unscrupulously degraded at a rather alarming rate (Uluocha \& Okeke, 2004).

Wetlands, as defined by Ramsar Convention [1971] "Areas of marsh, fen, peatland or water whether natural or artificial, permanent or temporary, with water that is static or flowing, fresh brackish or salt, including areas of marine water the depth of which at low tide does not exceed 6 meters."

There are, of course, other definitions of wetlands driven by the research purpose and the organization's mandate. For instance, studies interested in inland wetlands define wetlands as areas with water table at or near the soil surface for a significant part of the growing season. Asibor, (2009) asserts that, for an area to be considered a wetland, it must possess water, wetland plants and wetland soils. Wetlands are generally acclaimed for their wide range of functions and values in the ecosystem.

According to Asibor (2009), the major difference between wetland function and wetland value is that the functions are properties that wetlands naturally provides while wetland value are properties that are valuable to humans. Notable functions of wetlands according to Chidi \& Ominigbo, (2010) include flood control, groundwater recharge, coastal protection, sediment traps, atmospheric equilibrium and waste treatments as well as biological productivity, which provide nurseries for aquatic life and habitat for upland mammals such as deer, raccoons and Salamander. More importantly, wetlands are valuable to humans, as they aid in food production especially the cultivation of swamps for rice (rice paddies), cranberries, fish, salmon, etc. wetlands also provides humans with commercial animal populations; peatlands are useful in production of fuels just as wetlands 
are used as timber and/or fiber. Wetlands are also used extensively for recreational aesthetic and educational purpose. All over the world, wetlands are used as recreational sites in various ways - boating, picnics, yatching, fishing festival, boat regatta etc (Chidi \& Ominigbo, 2009; Asibor, 2009; Chidi \& Erhabor, 2009).

Nigeria is richly endowed with abundant wetlands ecosystem, the majority of which are found in the Niger, Benue and Chad basins (Fig. 1). Wetlands represent $2.6 \%$ of the country's area of about $923,768 \mathrm{~km}^{2}$. The Niger Delta is one of the most important wetlands in Nigeria, the largest in Africa and third largest area in the world.

Oyebande, et al., (2003) and Asibor, (2009), identified fourteen (14) major wetland belts in Nigeria. These includes: Sokoto-Rima, Komadugu Yobe, Lake Chad, Upper Niger and Kainji Lake, Middle Niger - Lokoja - Jebba - Lower Kaduna, Lower Benue - Makurdi, Cross River, Lower Niger, Niger Delta, Benin - Owena and Okomu, Lagos Lagoon and Lekki Peninsula, Lower Ogun River, Ologe Lagoon, Badagry and Yewa Creeks and the transboundary wetlands of the Upper Benue. Despite the existence of many important wetlands in Nigeria, most of them are not well documented and gazzetted (Chidi \& Ominigbo, 2010). For example, in the entire country, only eleven (11) wetland sites are recognized as Ramsar sites, both inland and coastal (Asibor, 2009). Even the Niger Delta, Nigeria's largest and richest biodiversity region, is yet to be recognized (Table 1) and gazetted as Ramsar site (Chidi \& Erhabor, 2009).

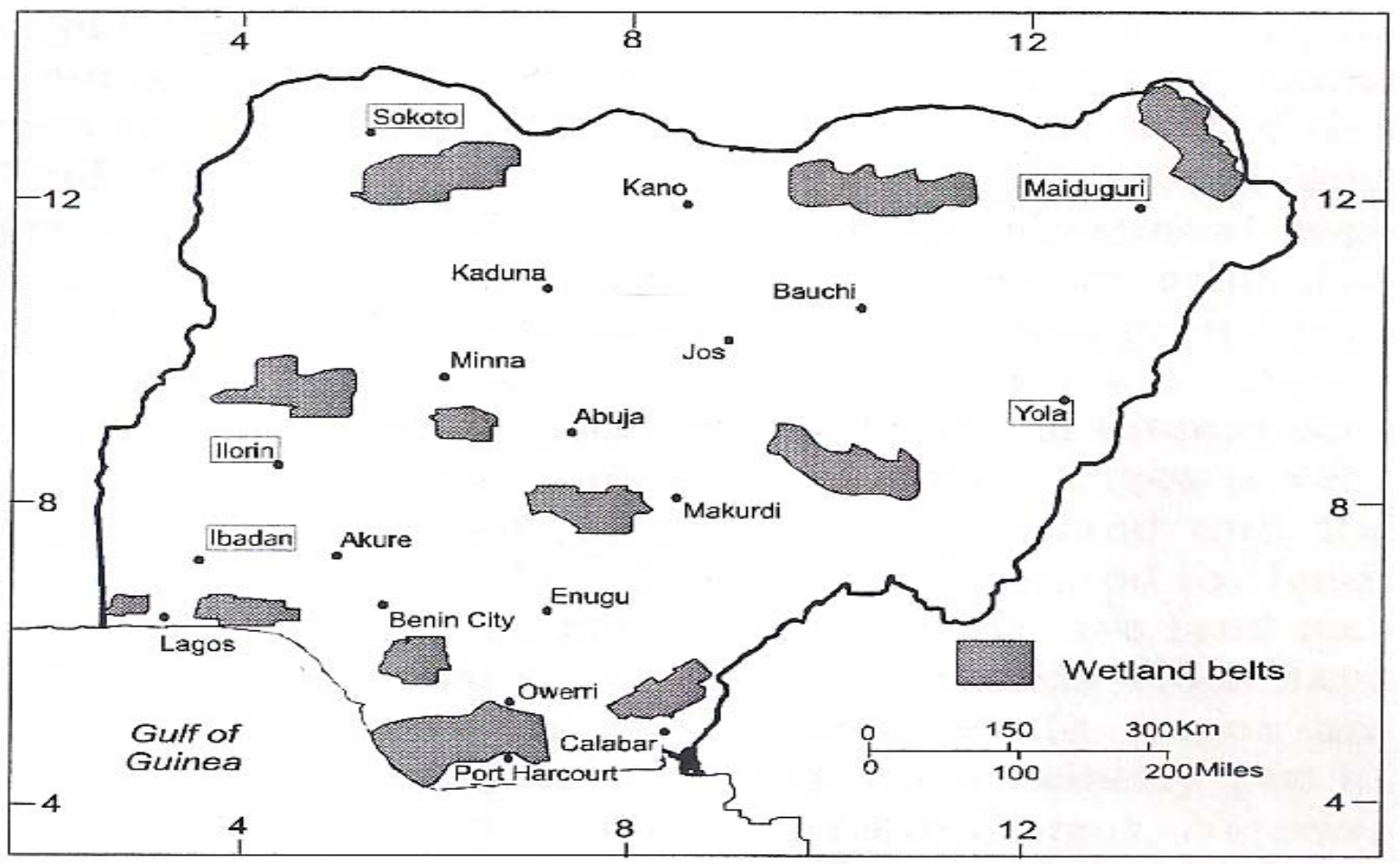

Fig. 1: Map of Nigeria Showing Wetland Belts (Source: Uluocha \& Okeke, 2004). 
These wetlands are however at the risk of degradation and biodiversity loss resulting from urbanization, climate change and mineral exploitation and processing (Uluocha \& Okeke, 2005; Akpofure, 2009; Asibor, 2009). The Nigerian coastal ecosystems do not only suffer disequilibria but also pronounced degradation with dire consequences on the food chain (Awosika, 1995; Aigbedion \& Iyayi, 2007). There is therefore the urgent need to study the coastal wetlands with the aim of conserving them as well as enhancing their functions and values.

Table 1: Nigeria's 11 Ramsar Sites (1, 076, 728 hectares)

\begin{tabular}{|c|c|c|c|c|c|}
\hline $\mathrm{S} / \mathrm{N}$ & Site & $\begin{array}{l}\text { Date of } \\
\text { Designation }\end{array}$ & State $(\mathrm{s})$ & Area (ha) & Co-ordinates \\
\hline 1 & $\begin{array}{l}\text { Nguru lake } \\
\text { (and Marma } \\
\text { Channel) } \\
\text { complex }\end{array}$ & $02 / 10 / 2000$ & $\begin{array}{l}\text { Jigawa } \quad \& \quad \\
\text { Yobe }\end{array}$ & 58,100 & $10^{0} 012^{0} 46^{\prime} \mathrm{E}$ \\
\hline 2 & $\begin{array}{l}\text { Apoi Creek } \\
\text { Forests }\end{array}$ & $30 / 04 / 2008$ & Bayelsa & 29,213 & $\begin{array}{l}05^{0} 47^{\prime} \mathrm{N} \\
0044^{\circ} \mathrm{E}\end{array}$ \\
\hline 3 & $\begin{array}{l}\text { Baturiya } \\
\text { Wetlands }\end{array}$ & $30 / 04 / 2008$ & Kano & 101,095 & $\begin{array}{l}12^{03} 1^{\prime} \mathrm{N} \\
010^{0} 29^{\prime} \mathrm{E}\end{array}$ \\
\hline 4 & $\begin{array}{l}\text { Dangona } \\
\text { Sanctuary } \\
\text { Lake }\end{array}$ & $30 / 04 / 2008$ & Yobe & 344 & $\begin{array}{l}12^{0} 48^{\prime} \mathrm{N} \\
010^{0} 44^{\prime} \mathrm{E}\end{array}$ \\
\hline 5 & Foge Islands & $30 / 04 / 2008$ & $\begin{array}{ll}\text { Kebbi } \quad \& \\
\text { Niger }\end{array}$ & 4,229 & $\begin{array}{l}10^{03} 0^{\prime} \mathrm{N} 004^{0} \\
33^{\prime} \mathrm{E}\end{array}$ \\
\hline 6 & $\begin{array}{l}\text { Lake Chad } \\
\text { Wetland }\end{array}$ & $30 / 04 / 2008$ & Borno & 607,354 & $\begin{array}{l}13^{0} 04^{\prime} \mathrm{N} \\
013^{0} 48^{\prime} \mathrm{E}\end{array}$ \\
\hline 7 & $\begin{array}{l}\text { Lower } \\
\text { Kaduna- } \\
\text { Middle Niger } \\
\text { Floodplain }\end{array}$ & $30 / 04 / 2008$ & $\begin{array}{l}\text { Kwara \& } \\
\text { Niger }\end{array}$ & 229,054 & $\begin{array}{l}08^{0} 51^{\prime} \mathrm{N} \\
005^{0} 45^{\prime} \mathrm{E}\end{array}$ \\
\hline 8 & $\begin{array}{l}\text { Maladumba } \\
\text { Lake }\end{array}$ & $30 / 04 / 2008$ & Bauchi & 1,860 & $\begin{array}{l}10^{0} 24^{\prime} \mathrm{N} \\
009^{0} 51^{\prime} \mathrm{E}\end{array}$ \\
\hline 9 & Oguta Lake & $30 / 04 / 2008$ & Imo & 572 & $\begin{array}{l}05^{0} 42^{\prime} \mathrm{N} \\
006^{0} 47^{\prime} \mathrm{E}\end{array}$ \\
\hline 10 & $\begin{array}{l}\text { Pandam \& } \\
\text { Wase Lake }\end{array}$ & $30 / 04 / 2008$ & Nasarawa & 19,742 & $\begin{array}{l}08^{0} 42^{\prime} \mathrm{N} \\
008^{0} 58^{\prime} \mathrm{E}\end{array}$ \\
\hline 11 & $\begin{array}{l}\text { Upper } \\
\text { Orashi } \\
\text { Forests }\end{array}$ & $30 / 04 / 2008$ & Rivers & 25,165 & $\begin{array}{l}04^{0} 53^{\prime} \mathrm{N} \\
006^{0} 30^{\prime} \mathrm{E}\end{array}$ \\
\hline
\end{tabular}

(Source: Asibor, 2009) 


\section{FRESHWATER RESOURCES AND ASSOCIATED CHANGES}

Water availability, vulnerability of natural and socio-economic systems, changes in land use, and a sound science base for developing policies for sustainable use of water resources are the major issues. Wetlands are key components of freshwater ecosystems and these include a variety of highly productive habitat types from flooded forests and floodplains to shallow lakes and marshes, but also saltwater ecosystems. Wetland ecosystems (Oyebande et al., 2002), may be grouped into three broad categories based on whether they are fresh or salty, natural or manmade:

(a) Freshwater:

(i) Riverine: perennial rivers and streams as well as inland deltas;

(ii) Seasonal and irregular rivers and streams and riverine flood plains, flooded grasslands;

(iii) Lacustrine ecosystems include permanent freshwater lakes and greater than 8 ha in area, as well as the seasonal lakes smaller than 8 ha, including floodplain lakes and ponds;

(iv) Palustrine system: permanent freshwater marshes on inorganic soils and dambos, peatlands, and freshwater springs and oases with surrounding vegetation;

(v) Forested wetlands such as shrub swamps, freshwater swamp forest and forested peatlands, including peat swamp forest.

(b) Manmade Wetlands:

(i) Aquaculture systems such as aquaculture ponds'

(ii) Agricultural wetlands - ponds, irrigated land and irrigation channels and seasonal flooded arable land;

(iii) Salt exploitation relics - salt plains and saline;

(iv) Urban excavations and wastewater transport and treatment areas; 
(v) Dams and their associated water storage areas such as reservoirs holding water for irrigation and other human uses.

(c) Saltwater Wetland Ecosystems:

(i) Marine environment - subtidal unvegetated shallow water $[<6 \mathrm{~m}$ deep] at low tide, subtidal aquatic vegetation and coral reefs;

(ii) Intertidal areas of rocky, marine shores, shores of mobile stones and shingle, mobile unvegetated mud, sand or salt flats, as well as salt marshes and mangroves;

(iii) Estuarine environment - subtidal estuarine waters, intertidal mud, sand or salt flats, and mangrove swamp as well as tidal freshwater swamp forest;

(iv) Lagoon and salt lakes: Brackish to saline lagoons, permanent to seasonal salt lakes.

\section{Distribution and Extent of Wetlands in the West/Central African Sahel}

Sahelian wetlands occur in areas where three major river/lake systems dominate the West and Central African Sahel. They are the Senegal and Niger Rivers and Lake Chad system, which had wetlands covering a total area of about $6.78 \times 10^{6}$ ha (Table 2). The Niger's inland delta in Mali alone accounted for $45 \%$ of the total. However, owing to the combined effects of droughts and water projects and the associated land use, more than $50 \%$ of the wetland area has been lost during the last four decades. Greater losses are expected with the projected impacts of climate change and when the dams currently under design and construction are completed. 
Table 2: Distribution and Extent of the Major Wetlands in the Sahel

\begin{tabular}{|l|l|l|l|}
\hline S/N & River/Lake System & $\begin{array}{l}\text { Area of Wetland } \\
{\left[10^{3} \mathrm{ha}\right]}\end{array}$ & Country/Countries \\
\hline 1. & Senegal Delta & 300 & Senegal, Mauritania \\
\hline 2. & Senegal Valley & 500 & $\begin{array}{l}\text { Senegal, Mauritania, } \\
\text { Mali }\end{array}$ \\
\hline 3. & Niger Inland Delta & 3000 & Mali \\
\hline 4. & $\begin{array}{l}\text { Niger fringing } \\
\text { floodplain }\end{array}$ & 300 & Nigeria \\
\hline 5. & $\begin{array}{l}\text { Sokoto and Rima } \\
\text { Valleys }\end{array}$ & $* 180$ & Nigeria \\
\hline 6. & $\begin{array}{l}\text { Hadejia Komadugu } \\
\text { floodplains }\end{array}$ & 400 & Nigeria \\
\hline 7. & Logone floodplains & 1100 & Cameroon, Chad \\
\hline 8. & Lake Chad floodplain & 1000 & Chad \\
\hline & Total & 6,780 & West African Sahel \\
\hline
\end{tabular}

*Recent estimates put the area at 180,000ha while intermediate and minor fadamas add a further 100,000ha (Source: Oyebande \& Balogun, 1992). 
Table 3: Wetland Values and functions

\begin{tabular}{|c|c|c|c|c|c|c|c|c|}
\hline & 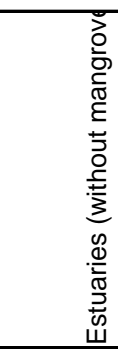 & $\begin{array}{l}0 \\
0 \\
0 \\
0 \\
\frac{1}{2} \\
\Sigma \\
\end{array}$ & $\begin{array}{l}n \\
0 \\
\tilde{0} \\
0 \\
0 \\
\bar{\Phi} \\
0 \\
0\end{array}$ & $\begin{array}{l}0 \\
\frac{n}{\bar{c}} \\
\frac{\pi}{0} \\
\frac{0}{0} \\
\frac{0}{4} \\
\end{array}$ & 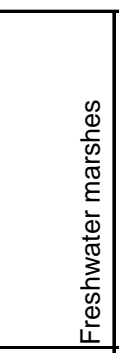 & 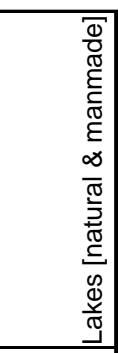 & 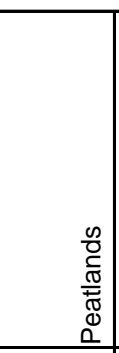 & 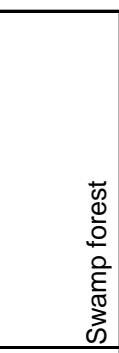 \\
\hline \multicolumn{9}{|l|}{ Functions } \\
\hline 1. Groudwater recharge & 0 & $\mathrm{O}$ & $\mathrm{O}$ & - & 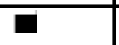 & " & $\bullet$ & $\bullet$ \\
\hline 2. Groundwater discharge & $\bullet$ & $\bullet$ & $\bullet$ & $\bullet$ & $\mathbf{E}$ & $\cdot$ & • & - \\
\hline 3. Flood control/regulation & $\bullet$ & " & O & - & 政 & " & $\bullet$ & - \\
\hline 4. Shoreline stabilisation/Erosion control & $\bullet$ & - & - & $\bullet$ & 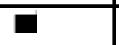 & 0 & 0 & 0 \\
\hline 5. Sedimen/toxicant retention & $\bullet$ & E & $\bullet$ & E & $\overline{\mathbf{E}}$ & E & $\overline{\mathbf{n}}$ & $\mathbf{E}$ \\
\hline 6. Nutrient retention & $\cdot$ & - & $\cdot$ & - & - & - & - & - \\
\hline 7. Biomass export. & $\bullet$ & E & $\bullet$ & E & $\bullet$ & - & 0 & • \\
\hline 8. Storm protection/windbreak & $\cdot$ & E & $\cdot$ & $\mathrm{O}$ & $\mathrm{O}$ & $\mathrm{O}$ & $\mathrm{O}$ & - \\
\hline 9. Micro-climate stabilisation & $\mathrm{O}$ & $\bullet$ & O & $\bullet$ & $\bullet$ & $\bullet$ & $\mathrm{O}$ & • \\
\hline 10. Water Transport. & $\bullet$ & $\bullet$ & $\mathrm{O}$ & $\bullet$ & 0 & $\bullet$ & 0 & 0 \\
\hline 11. Recreation/Tourism & $\bullet$ & - & E & $\bullet$ & - & - & - & • \\
\hline \multicolumn{9}{|l|}{ Products } \\
\hline 1. Forest resources. & $\mathrm{O}$ & $\bar{\square}$ & O & $\bullet$ & $\mathrm{O}$ & $\mathrm{O}$ & $\mathrm{O}$ & $\overline{\mathbf{n}}$ \\
\hline 2. Wildlife resources [including fowls]. & $\mathbf{n}$ & - & • & - & - & - & - & $\bullet$ \\
\hline 3. Fisheries & E & E & $\bullet$ & E & E & E & $\mathrm{O}$ & • \\
\hline 4. Forage resources. & • & - & O & - & - & $\mathrm{O}$ & $\mathrm{O}$ & $\mathrm{O}$ \\
\hline 5. Agricultural resources. & & $\mathrm{O}$ & $\mathrm{O}$ & - & - & " & - & $\mathrm{O}$ \\
\hline 6. Water supply & & $\mathrm{O}$ & O & $\cdot$ & - & - & - & - \\
\hline \multicolumn{9}{|l|}{ Attributes } \\
\hline 1. Boilogical diversity. & - & $\bullet$ & $\bullet$ & - & $\bullet$ & $\mathbf{\square}$ & $\bullet$ & • \\
\hline 2. Uniqueness to culture/heritage. & - & - & $\bullet$ & $\bullet$ & $\bullet$ & - & - & • \\
\hline
\end{tabular}

N/B:

O Absent or exceptional

- Present

- Common and important value of that wetland type (Source: Dugan, 1990)

In addition, thirteen (13) countries of the region are coastal in nature. Between Senegal and Nigeria - Cape Verde islands included - the coastline is about 15,000 $\mathrm{km}$ long (Table 3). The major rivers reaching this coast are from North to South: the Senegal, the Volta and the Niger rivers (Mahe, 1993). The different countries belong to two different Large Marine Ecosystems: the Canary Current LME (from Cape Verde to Guinea Bissau) and the Gulf of Guinea LME (from Guinea Bissau to Nigeria) (Sherman et al., 1993). 


\section{Climate Change Impact on Wetland Resources}

There is ample evidence that climate variability and change already affecting Nigeria's water and wetland resources (Table 4). For example, several large river and lake systems have suffered marked reductions in flow rates and in the lengths of their networks in response to reduced rainfall and higher evaporation, e.g. Sokoto river system in NW Nigeria, 1965-1995. Indeed, since the mid-sixties (40 years) rainfall has decreased by about 15 to $20 \%$ in average over West Africa and runoff have decreased by about 30 to $50 \%$ or more over most rivers (Oyebande, et al., 2002).

Table 4: Consequences of climate change on coastal zones of some West African countries with a $0.5 \mathrm{~m}$ sea level rise by 2100

\begin{tabular}{|c|c|c|c|c|c|}
\hline & $\begin{array}{l}\text { Land lost by } \\
\text { erosion } \\
\left(\mathrm{km}^{2}\right)\end{array}$ & $\begin{array}{l}\text { Areas to be } \\
\text { flooded } \\
\left(\mathrm{km}^{2}\right)\end{array}$ & $\begin{array}{l}\text { Population at } \\
\text { risk } \\
\text { (thousands) }\end{array}$ & $\begin{array}{l}\text { Economic } \\
\text { value at risk } \\
\text { (millions of } \\
\text { US } \$^{1} \text { ) }\end{array}$ & $\begin{array}{l}\text { Protection } \\
\text { costs } \\
\text { (millions of } \\
\text { US \$) }\end{array}$ \\
\hline Senegal & $28-44$ & 1,650 & 69-104 & $345-464$ & 146-575 \\
\hline Gambia & n.a. & 45.89 & n.a. & n.a. & n.a. \\
\hline $\begin{array}{l}\text { Côte } \\
\text { d'Ivoire }\end{array}$ & n.a. & 471 & 1,475 & $4,710^{2}$ & n.a. \\
\hline Benin & 22.5 & 17.5 & & & 215.25 \\
\hline Nigeria & $78-145$ & 8,864 & 1,600 & $9,003.3$ & $223-319$ \\
\hline
\end{tabular}

Note: na $=$ Not Available

(Source: Adam, 1994)

The potential impacts of climate change on water and wetland resources both inland and in the coastal zones could be devastating. That is why vulnerability and adaptation studies are so important, not only to identify issues and problems but also to raise awareness among the scientific community and national 
authorities on the risks linked with climate change. General strategies available for adapting to climate change include:

(i) Preventing losses: measures taken in advance to accomplish this

(ii) Reducing losses to a tolerable level;

(iii) Spreading or sharing losses;

(iv) Changing utilisation or activity that is no longer viable;

(v) Changing the location of an activity (e.g. re-siting of the Hydroelectric Power Plant where there is more water;

(vi) Restoring vulnerable site.

It is imperative to implement preventive and coping actions because it is certain that the hydrological cycle will change as a result of increased global temperature in the order of $1^{\circ}$ to $6^{\circ}$ by the year 2100 ; moreover;

(i) Anticipated coping is more effective and less expensive than emergency coping, implemented at the last minute;

(ii) Climate change could occur faster and be more exacerbated than the indications of current estimates;

(iii) Immediate advantages can be derived from coping better with climate variability and extreme atmospheric events;

(iv) Immediate advantages can be derived from giving up unsuitable policies and practices.

Integrated approach to water resource management is inescapable strategy with the decline in the flows of West Africa's rivers due to continuous fall in precipitation since the sixties: the decline in flow is estimated at 40 to $60 \%$ since the late sixties (Oyebande, et al., 2002). This reduction in flow has had direct consequences on the replenishment of most of West Africa's dams as it has resulted in water shortage for agriculture, hydroelectric power generation and urban water supply.

West Africa's main river systems are shared among several countries. There are some eleven (11) transboundary rivers and lakes, which are shared by at least three countries, a situation which makes basin cooperation and integration an imperative. 
Specific adaptation strategies include:

(i) Pollution Abatement;

(ii) Improvement of the Efficiency of Water Supply Infrastructures- urban and irrigation structures;

(iii) Artificial rain making;

(iv) Interbasin water transfer;

(v) Adopt appropriate adaptation strategy for the coastal zone.

A programme of action, based on the identified issues, needs and gaps as well as challenges, is certainly required. Such an action programme should also seek to identify early and operationalise the priority strategies.

\section{Conclusion}

Future approach to the use and management of water and wetland resources are expected to be proactive, adopt a more efficient allocation mechanism based on cost recovery and private sector driven initiative. Strong demand management and stakeholder participation are all the elements of the new agenda for sustainable water and wetland management. Strengthen wetland conservation and protection against the twin impact of climate change and human activities: support national and regional wetland conservation programmes, establish National Wetland Management Committee, improve quality and quantity of information on national wetland ecosystems, and develop methodologies for assessing the nature and importance of wetland functions now and under climate change, develop national policies, which support wetland conservation and promote appropriate legislation. It is suggested that additional wetlands be created, where possible to make for extinct and degraded wetlands. The promotion of the practice of Environmental Impact Assessment before any major industrial project is sited is very desirable. This will help in reducing the adverse impacts of industrialization on wetlands in the country.

\section{References}

Adam, K.S. (1995). Vulnerability assessment and coastal management program in the Benin coastal zone. In: Beukenkamp, P. et al. (eds) "World Coast Conference. Proceedings". Coastal Zone Management Centre, The Hague, Vol. 2, 489-501.

Aigbedion, I and Iyayi, S.E (2007). Environmental Effects of Mineral Exploitation in Nigeria. International Journal of Physical Sciences, 2(2):33 - 38. 
Akpofure, R (2009). Environmental Sciences: An Introduction. Ibadan:Kraft Books Ltd.

Asibor, G (2009). Wetlands: values, uses and challenges. A Paper presented to the Nigerian Environmental Society at the Petroleum Training Institute, Effurun, $21^{\text {st }}$ November, 2009.

Awosika, L.F. (1995). The West African coastal zone: a regional appoach to the process of integrated coastal zone management. In: Beukenkamp, P. et al. (eds) "World Coast Conference. Proceedings". Coastal Zone Management Centre, The Hague, Vol. 2, 697704.

Bonfis, L (2001). Hot desert albedo and climate change: Mid Holocene Moonsoon in North Africa. International Journal of Climate Change. 4:3724 - 3737.

Chidi, H.O and Erhabor, F.O (2009). Biodiversity of wetlands and wealth creation in Niger Delta. International Journal of Development Studies, 4(3):108 - 115

Chidi, O.H and Ominigbo, O.E (2010). Climate change and coastal wetlands: Nigeria in perspective. International Journal of Environmental Issues, 7(2): 216 - 223.

Dietrich, V.S (2005). Boidiversity and Climate Change. Asian Institute of Technology Press.

Dugan, P.J.(1990) Wetland Conservation - A review of current issues and required action.

IUCN - World Conservation Union. Gland, Switzerland.

Kusler, J (2003). Climate Change in Wetland Areas. Part 1: Potential Wetland Impacts and Interactions. Acclimations: New York: National Wetlands Research Centre.

Mahe, G. (1993). Les écoulements fluviaux sur la façade atlantique de l'Afrique. Etude des éléments du bilan hydrique et variabilité interannuelle, analyse de situations hydroclimatiques moyennes et extrêmes. ORSTOM ed., Paris, Coll. Etudes et Thèses, 438 pp.

Nwankwoala, H.O (2011). An integrated Approach to sustainable development and management of groundwater resources of Nigeria. Journal of Geology and Mining Research, 3(5):123 - 130

Offodile, M.E (2006). Overview on sustainable development and management of water resources in Nngeria. Journal of Mining and Geology, Vol.42 (1), pp57 - 61.

Onyeka, E.M and Adaobi, V.M (2008). Climate change: A challenge for Environmental Education in the $21^{\text {st }}$ Century. Multi-disciplinary Journal of Research Development, 10(5):40 - 46.

Oyebande, L. \& I. Balogun (1992) Water resources management in the semi-arid regions of Nigeria, Canadian Journal of Dev. Studies, Special issue, 209-226.

Oyebande, L; Amani, A; Mahe, G and Niang-Diop, I (2002). IUCN-BRAO Working Paper on Climate Change, Water and Wetlands in West Africa: Building linkages for their integrated management.

Oyebande, L; Obot, E.O and Bdiliya, H.H (2003). An inventory of wetlands in Nigeria. Report prepared for World Conservation Union - IUCN, West African Regional Office, Quagadougou, Burkina Faso. 
Sherman, K., Alexander, L.M., Gold, B.D. (eds) (1993). Large Marine Ecosystems. Stress, Mitigation and Sustainability. AAAS Press, Washington, 376 pp.

Tijani, M.N (2006). The need for action- driven vision and sustainable management of water resources in Nigeria. Journal of Mining and Geology, Vol.42(1), pp31 - 40.

Uluocha, N.O and Okeke, I.C (2004). Implications of wetlands degradation for water resources management:Lessons from Nigeria. Geojournal, 16:151 - 154

United Nations Environmental Programme (UNEP) (2007). The status of the Nigerian Coastal Zones. Retrieved online from www.unep.org/abdjanconvention/docs. on August 2nd, 2011. 